\title{
The Development of Learning Media Based on Mind Map in Exposition Text
}

\author{
Visi Wintan Reka Widya Tampubolon \\ Department of Indonesian Language Education on \\ Postgraduate Program \\ State University of Medan \\ Medan, Indonesia \\ visiwrwt2707@gmail.com
}

\author{
Abdurahman Adisaputera \\ Department of Indonesian Language Education on \\ Postgraduate Program \\ State University of Medan \\ Medan, Indonesia
}

\author{
Daulat Saragi \\ Department of Indonesian Language Education on Postgraduate Program \\ State University of Medan \\ Medan, Indonesia
}

\begin{abstract}
This study aims to produce mind map based learning media on exposition text for Vocational High School Tritech Informatika. The research method used is the research method and the development of Research and Development which refers to the Borg and Gall model. The results of individual trials are stated in very good category with an average of $86.80 \%$. Small group trials obtained an average percentage of $89.12 \%$ with very good categories. The results of the trial trials of 32 students were expressed in the excellent category with a total percentage of an average of $91.27 \%$. Material validation obtained results of assessment on aspects of feasibility of the content stated to be very good with an average of $91.40 \%$, assessment on aspects of presentation feasibility was stated to be very good with an average of $91.34 \%$, and the results of language assessment were declared very good with a total percentage of average $93.26 \%$. The results of validation by design experts were stated to be very good with a total percentage of an average of $86.25 \%$. Effectiveness is known from the average value of the pretest obtained is 70.68 in the sufficient category and the average posttest value is $80.21 \%$ in the good category. This proves that mind map-based learning media on exposition text material is feasible, easy, and effective for use in students. This research has implications for fostering students creativity and making the learning process of text exposition fun in accordance with the 2013 curriculum.
\end{abstract}

Keywords-development of learning media; exposition text; mind map

\section{INTRODUCTION}

Learning is essentially a communication process and an activity that involves a person in an effort to obtain positive knowledge, skills and values by utilizing various learning resources. Learning resources are an important element in the development of learning media. The use of learning media in learning can generate interest, motivation, help students improve understanding, present data with interesting and reliable, facilitate interpretation of data, and compress information. The use of learning media by utilizing information and communication technology has an important role so that it can help learning activities. [1] Sanjaya (2008: 23 ) states that teachers can carry out the role of facilitator in the learning process.

This is evidenced by the results of preliminary observations made at School of Tritech Informatika Medan through interviews with the School of Medan Tritech Informatika Medan principal who said that the facilities and infrastructure in the school were very adequate. This is evidenced by the availability of computer laboratories, projectors, and supporting tools in applying computer networks and students are required to bring laptops in private to facilitate learning activities for all subjects

From the results of direct observation during the learning process, it can be concluded that the teacher does not have the skills to develop learning media by utilizing available school facilities. Teachers who tend to use the same learning method and use print media in the form of text teaching materials make students less motivated in learning. The teacher has not used media which is to arouse students' interest and curiosity in the subject matter.

Therefore, it is necessary to apply appropriate learning media for exposition text material. Mind maps are very suitable for use in exposition texts. Students can first put forward ideas that are accompanied by fact collection and then summarize all of them to form an idea or argument.

Mind maps will help students in composing and storing as much information as possible and how to classify it naturally is to give easy and direct access to something desired. With various advantages, mind maps can facilitate students in writing Indonesian texts.

The step of using mind maps is usually done on blank paper and drawing colors that connect one branch to another. The use of mind maps in this study was applied in the form of learning media. This mind map based learning media will be 
used in exposition text material. Mind map-based learning media will later become additional learning media for students in understanding exposition text material that requires students to think creatively and easily pour ideas and ideas into understanding exposition texts.

Mind map based learning media on the exposition text will be designed in Adobe Flash CS8 programs which are adobemade programs or software. Learning media that is developed with Adobe Flash CS8 has several advantages compared to other media that can present audiovisually material followed by voice explanation so that it is more interesting and fun and motivates students to learn about exposition texts. This learning media is used individually because it directly stores data and values of students' work on exposition text material. This learning media can also be used repeatedly so that students who do not understand the subject matter can repeat their learning activities independently, considering each student has a different level of absorption.

The formulation of the problem of this research is how the development process of mind map-based learning media on exposition text material in school of Tritech Informatika Medan, how feasibility of mind map-based learning media developed on exposition text material of class school of Tritech Informatika Medan, how the effectiveness of map based learning media thoughts developed on exposition text.

In line with the research problem, the purpose of this research and development is to describe the development process of mind map based learning media on exposition text, describing the feasibility of developing mind map based learning media on exposition text, describing the effectiveness of developing mind map based learning media on exposition text material in students school of Tritech Informatika Medan.

Based on the description above, the researcher is interested in conducting research that produces a product regarding the development of mind map based learning media on exposition text.

\section{LITERATURE REVIEW}

\section{A. Instructional Media}

The word media comes from Latin, namely medius which literally means middle, intermediary, or introduction [2]. In the learning process, the media aims to make it easier for students to understand the subject matter delivered by the teacher. In addition, it stimulates students to remember what they have learned, in addition to providing new learning stimuli. Good media will enable students to provide feedback, feedback, and encourage students to do the right practices.

Can clarify and simplify abstract concepts, and enhance absorption or learning retention, but now its function must be able to motivate learning, generate student creativity, and learn high level thinking [3].

So based on some understanding from the experts, it can be concluded that the learning media is a tool in conveying messages that can stimulate students' thoughts, feelings, attention, and willingness so that they can encourage a conducive, purposeful, controlled learning process, and can increase motivation, stimulation, and facilitate students in understanding the material presented.

\section{B. Mind Map}

Chatib [4] said mind mapping was first introduced by Tony Buzan, a psychologist from the UK. He is the inventor of mind maps that are applied in all fields of life, especially in the field of education and learning. Buzan [5] states that mind maps are the easiest way to place information into the brain and take information out of the brain.

Riyanto [6] expressing this mind map is intended to make students more skilled at exploring the initial knowledge already possessed and acquiring new knowledge according to their learning experience.

From some of the opinions above, it can be concluded that mind maps are the maximum utilization of the brain's ability to store and understand all information and show the existing inter-information relationships. In the learning process, mind maps are very helpful for students in understanding well the existing learning.

Mind maps can help students organize and store as much information as they want, as well as classifying the information so as to enable them to have good memory of all the desired information. Mind maps have a series of activities that help make life easier and more successful, because summary is an effort to improve and remember information at any time needed quickly and easily. Making a mind map is not difficult and does not require large costs. However, the results of the mind map will make a great thought.

Steps in creating a mind map, which is first to start from the middle of a blank paper whose sides are placed horizontally, because starting from giving the brain the freedom to spread in all directions and to express itself more freely and naturally. Use pictures or photos for a central idea, because an image means a thousand words and helps to use imagination. A hit picture will be more interesting, keep it focused, help concentrate, and activate the brain. Use color because the color brain is as interesting as the image. Color makes mind maps more lively, and fun. Connect the main branches to the center image and connect the second and third level branches to the first and second level branches, and so on. This is done because the brain works according to the association. The brain likes to associate two, three, or four things at once. When we connect branches, we will more easily understand and remember. Make curved lines, not straight lines. Straight lines will boring the brain. Arched and organic branches, like tree branches, are far more attractive to the eye. Use one keyword for each line, because a single keyword gives mind maps more power and flexibility. Use images for each branch, because like the central picture will give a thousand words meaning.

Mind map-based exposition text learning instructional media will be designed in Adobe Flash CS5 programs which are adobe-made programs or software. Learning media developed with Adobe Flash CS5 have several advantages compared to other media that can present material audiovisually followed by voice explanations so that it is more 
interesting and fun and motivates students to learn about exposition texts. This learning media is used individually because it directly stores data and values of students' work on exposition text material. This learning media can also be used repeatedly so that students who do not understand the subject matter can repeat their learning activities independently, considering each student has a different level of absorption. The goal is for students to exploit thought through mind maps in understanding exposition texts in the form of learning media arranged as student teaching materials.

Mind maps are very effective used to bring up hidden ideas that students have and make associations between them. Mind maps are also useful for organizing information that is owned, so that students' learning and ways of thinking are more effective and efficient in achieving learning goals. The human brain works to process information through observation, reading, or listening to something in the form of functional relationships between parts (concepts, keywords), not separate from each other and not in complete cataract narratives. If you want a material that can be understood easily, then the method of learning must be in accordance with the way the brain works. If the brain is used optimally, every opportunity can be used for self-learning in everything.

\section{Exposition Text}

The lexical exposition comes from the English language 'exposition', which means opening or starting. While the term exposition text according to [7] says the exposition text of a text which aims to inform, explain, analyze, and describe something.

Priyatni [8] states that the exposition text is a text used to convince the reader of the opinions expressed with a number of supporting arguments. Exposition text usually contains an issue or issue about a particular topic and a statement that indicates a position in response to the issue or issue.

Exposition is a variety of discourses intended to explain or describe things that can expand or increase the knowledge and views of the reader. [9]

Based on some of the opinions above, it can be concluded that the exposition text is a form of writing that attempts to explain a subject by explaining how, peeling, or describing something so that it enhances the reader's knowledge.

\section{METHOD}

The study was conducted at Vocational High School Tritech Informatika Medan located at Jalan Bhayangkara No. 484 Medan. This research and development population is a first grade student school of Tritech Informatika Medan. To see the effectiveness of the media developed, researchers took two classes as samples taken in a random cluster.

This research is a type of research and development which refers to the Borg and Gall model. The stages of development are the initial study phase, initial product development, and product trials.

The data obtained are data about the state of Indonesian language learning media on exposition text material that has been developed. This data is collected through expert validation, questionnaires distributed to students. Research instruments for validators and individual tests, small groups and limited field groups are made in the form of a Likert Scale that has been given a score as shown in table I. [10]

TABLE I. Criteria of Validation Instrument Items

\begin{tabular}{|c|l|c|}
\hline No. & \multicolumn{1}{|c|}{ Answer } & Score \\
\hline 1. & Very good & 4 \\
2. & Good & 3 \\
3. & Poor & 2 \\
4. & Very poor & 1 \\
\hline
\end{tabular}

Then analyzed quantitatively descriptively, namely calculating the percentage of indicators for each category of teaching materials developed. From the results of the calculation of the formula above, a number is generated in percent form. The score classification is then converted into a classification in the form of percentages [10] then interpreted with qualitative sentences listed in table II.

TABLE II. Criteria for Percentage of Indicators

\begin{tabular}{|l|c|}
\hline \multicolumn{1}{|c|}{ Criteria } & Percentage \\
\hline Very good & $81 \% \leq 100 \%$ \\
Good & $61 \% \leq 80 \%$ \\
Medium & $41 \% \leq 60 \%$ \\
Not good & $21 \% \leq 40 \%$ \\
Very poor & $0 \% \leq 20 \%$ \\
\hline
\end{tabular}

\section{RESULT AND DISCUSSION}

This research and development process is carried out in several stages, namely preliminary studies, initial product development stages and trial stages. In the preliminary study phase, needs analysis was carried out by distributing questionnaires to 2 teachers and 32 students at Vocational High School Tritech Informatika Medan.

The process of implementing the development of teaching materials in stage I is to bring up ideas / ideas by carrying out a preliminary study. The preliminary study was carried out by conducting a field survey (needs analysis) and literature survey. The initial product development stage is the validation of material content and learning design, product revision and assessment and suggestions by the teacher. The initial product developed was mind map-based learning media on exposition text material in first grade.

The results of the questionnaire distributed to teachers and students were obtained. Some teachers $(75 \%)$ stated that they did not know the developed teaching materials while most students $(91.66 \%)$ stated that they did not know the developed teaching materials. 
All teachers (100\%) stated that they did not use teaching materials developed in the learning process and $(84.72 \%)$ students stated that they had not used teaching materials developed in accordance with the 2013 curriculum. All teachers $(100 \%)$ stated that they needed teaching materials developed in accordance with the 2013 curriculum in the learning process and most students $(86.78 \%)$ stated that they needed ingredients teaching that is developed based on media literacy in the learning process.

The feasibility of learning media will explain the four components of feasibility which include content feasibility, language feasibility, presentation feasibility, and graphic feasibility. The feasibility of the learning media was obtained after going through a validation process by material experts and teaching material design experts. The feasibility of learning media is done by validating the product by material experts and learning design experts. Every acquisition of validation results is classified in the form of percentage.

Content feasibility consists of four sub-components which include material suitability with core competencies and basic competencies, material accuracy, material up-to-date and encouraging curiosity. The results of the assessment on the sub-component of material suitability with core competencies and basic competencies are stated to be very good with a total percentage of $93.75 \%$.

The results of the assessment on the sub-component of material accuracy are stated to be very good with a total percentage of $91.07 \%$. The results of the assessment on the sub component of material updates are stated to be very good with a total percentage of $90 \%$. The results of the assessment on the sub-components encourage curiosity to be declared very good with a total percentage of $93.75 \%$. The average amount of overall feasibility of the contents is stated to be very good with a total percentage of $91.40 \%$.

Feasibility of presentation consists of three subcomponents which include presentation techniques, presentation of learning, and completeness of presentation.

The results of the assessment on the sub-component of the presentation technique are stated to be very good with a total percentage of $93.75 \%$. The results of the assessment on the sub-components of the presentation of learning are stated to be good with a total percentage of $83.33 \%$. The results of the assessment on the completeness of the sub-components of the presentation were stated to be very good with a total percentage of $93.75 \%$. The average number of overall presentation eligibility is very good with a total percentage of $91.34 \%$.

Language feasibility consists of six sub-components that include straightforward, communicative, dialogical and interactive, suitability with the level of development of students, the clutter and integration of the flow of thought, and the use of terms, symbols and icons.

The results of the assessment on straightforward subcomponents are stated to be very good with a total percentage of $87.5 \%$. The assessment results on the communicative subcomponent are stated to be very good with a total percentage of $87.5 \%$. Assessment results on dialogical and interactive sub-components are stated to be very good with a total percentage of $93.75 \%$. The results of the assessment on the sub-component of conformity with the level of development of students are stated to be very good with a total percentage of $93.75 \%$.

The results of the assessment on the sub-components of the wrestling and cohesiveness of the mind flow are stated to be very good with a total percentage of $100 \%$. The results of the assessment on the sub-components of the use of terms, symbols and icons are stated to be very good with a total percentage of $100 \%$. The average number of overall language eligibility is stated to be very good with a total percentage of $93.26 \%$.

The feasibility of graphics consists of three subcomponents which include the size of teaching materials, the cover design of teaching materials, and the design of the contents of teaching materials.

The results of the assessment on the sub-component of the text display are declared "good" with a total percentage of $82.14 \%$. The results of the assessment on the sub components of the image display are stated to be very good with a total percentage of $91.66 \%$. The results of the assessment on the attractiveness sub-component are stated to be good with a total percentage of $83.75 \%$. the assessment results in the integrated sub-component are very well with a total percentage of $87.5 \%$. The average number of gratuity eligibility is stated to be very good with a total percentage of $86.25 \%$.

Revision activities are carried out when the learning media has been created and then validated by material experts and design experts based on the products that have been created namely instructional materials in the form of learning media. Researchers conducted several revisions to teaching materials developed based on suggestions and improvements from material experts and learning design experts. Examples are improvements to writing errors (word writing and number writing).

The product development of mind map-based learning media on the exposition text was developed by taking into account aspects of learning material and learning instructional media design. The product development research that has been carried out is directed to produce a product in the form of learning media in the form of learning media in exposition text learning for first grade students that is used to improve the learning process and students' competencies. Therefore, in the process this research was carried out with a preliminary study. Then designing teaching materials, conducting product validation, revising and refining based on validation data analysis from material experts, teaching material design experts, followed by individual trials, small group trials, and limited field trials so that teaching materials are suitable for use in accordance with the characteristics of the field of study and students as users.

In theory, learning media learning is an important competency to provide awareness about the content and impact of the media and to be a control for individuals in using the media so that they can choose internet content as needed. Teachers who play a role as parents of students at 
school should properly master the learning media because learning media are also needed to educate students. Learning media does not have to be considered as an ability to analyze but is an awareness of media content so that learning media do not reduce interest in the media but rather recognize goals and help take alternative steps so that media messages become a tool to achieve goals so that they can appreciate media content.

The results of the needs analysis of teachers and students, namely all teachers $(100 \%)$ stated that they needed learning media developed in accordance with the 2013 curriculum in the learning process and most students said that they needed learning media developed based on mind maps in the learning process.

Validation of learning media is carried out by material experts and media design experts. Assessment conducted by material experts consists of three aspects of assessment, namely aspects of content feasibility, feasibility of presentation and assessment of language. The results of the assessment on the aspect of feasibility of the content were stated to be very good with an average percentage of $91.40 \%$. Assessment of the aspects of presentation feasibility was stated to be very good with a total percentage of an average of $91.34 \%$. The results on language assessment were stated to be very good with a total percentage of an average of $93.26 \%$. The results of validation by design experts were stated to be very good with a total percentage of an average of $86.25 \%$.

The stages of the trial of teaching materials were carried out with 3 processes, namely individual trials, small group trials and limited field trials. Product trials were conducted to identify the lack of learning media and student responses to mind map-based learning media on exposition text material.

The results of the individual trial 3 student assessment were stated in the very good category with a total percentage of an average of $86.80 \%$. The results of small group trials on 9 students assessed learning media gained an average percentage of $89.12 \%$ with very good categories. Limited field trials were conducted to determine the extent to which the usefulness of mind map based learning media on exposition text material for students. The results of the trial trials of 32 students were expressed in the excellent category with a total percentage of an average of $91.27 \%$. This means that mind map-based learning media in the exposition text has met the needs of learning.

The effectiveness of mind map-based learning media on exposition text material is obtained from student learning outcomes. This test was conducted on 32 students of Tritech Medan Vocational High School. This test is also carried out in two stages: pretest and posttest.

The pretest obtained data that the value of students before using learning media had not yet reached completeness. It is known from the average value that the average value obtained is 70.68 in the sufficient category. Postes that are done to obtain student value data after using learning media have reached completeness. It is known from the average value that the average value obtained is $80.21 \%$ in the good category.
The value of the learning outcomes above indicates that the use of mind map based learning media on exposition text material makes the learning value of exposition text learning values better. Improving learning outcomes is proof that mind map-based learning media on exposition text material will be effective if used by students and teachers in learning. Thus, there are differences in student learning outcomes using mind map based learning media on exposition text material. So it can be concluded that mind map based learning media on exposition text material is feasible and effective to be used in learning Indonesian in exposition text material.

The findings of the research that have been described above can be concluded that the results of developing mind map based learning media for the feasibility of teaching materials are considered feasible in the "very good" category and for students' learning outcomes are declared able to improve student learning outcomes in writing short story based on media literacy.

The benefits derived from the use of teaching materials are the concepts presented are easy to learn, understand and systematic. Teaching materials provide opportunities for students to learn according to their own pace independently, learning to be more focused and not cause boredom because it is equipped with material, sample analysis and practice questions. The repetition that must be done when looking at the scores obtained makes students better understand the material.

\section{CONCLUSION}

Based on the formulation of the problem, the purpose of the study, the results of research and discussion in the research on the development of mind map based learning media on this exposition text material can be summarized as follows:

1. Mind map based learning media on exposition text material for students of student of Vocational High School Tritech Informatika Medan is declared eligible and is suitable for use as a medium of student self-learning. This is obtained based on the results of the assessment of material experts and design experts on learning media. Validation of learning media is carried out by material experts and media design experts. Assessment conducted by material experts consists of three aspects of assessment, namely aspects of content feasibility, feasibility of presentation and assessment of language. The results of the assessment on the aspect of feasibility of the content were stated to be very good with an average percentage of $91.40 \%$. Assessment of the aspects of presentation feasibility was stated to be very good with a total percentage of an average of $91.34 \%$. The results on language assessment were stated to be very good with a total percentage of an average of $93.26 \%$. The results of validation by design experts were stated to be very good with a total percentage of an average of $86.25 \%$.

2. The development process of mind map-based learning media on exposition text material is carried out in three stages: preliminary study stage, initial product development and product testing. The results of the individual trial 3 student assessment were stated in the 
very good category with a total percentage of an average of $86.80 \%$. The results of small group trials on 9 students assessed learning media gained an average percentage of $89.12 \%$ with very good categories. The results of the trial trials of 32 students were expressed in the excellent category with a total percentage of an average of $91.27 \%$.

3. Mind map based learning media on exposition text material is declared effective to generate student learning activities and results. This is evidenced from the test of student learning outcomes in writing exposition text. The pretest obtained data that the value of students before using learning media had not yet reached completeness. It is known from the average value that the average value obtained is 70.68 in the sufficient category. Postes that are done to obtain student value data after using learning media have reached completeness. It is known from the average value that the average value obtained is $80.21 \%$ in the good category.

\section{REFERENCES}

[1] Sanjaya, Wina. 2008. Strategi Pembelajaran Berorientasi Standar Proses Pendidikan. Jakarta: Kencana Prenadamedia Group

[2] Arsyad, A. 2005. Media Pembelajaran. Jakarta: Grafindo Persada.

[3] Rusman. 2013. Model-Model Pembelajaran. Jakarta: Rajawali Press.

[4] Chatib, Munif. 2015. Kelasnya Manusia: Memaksimalkan Fungsi Otak Belajar dengan Manajemen Display Kelas. Bandung: Kaifa.

[5] Buzan, Tony. 2013. Buku Pintar Mind Map. Jakarta: Gramedia Pustaka

[6] Riyanto, Yatim. 2010. Paradigma Baru Pembelajaran. Jakarta: Penerbit Kencana Prenada Media Group.

[7] Dalman. 2014. Keterampilan Menulis. Bandung: Rajawali.

[8] Priyanti, Indah Tri. 2014. Desain Pembelajaran Bahasa Indonesia. Jakarta: Bumi Aksara

[9] Yaumi, Muhammad. 2014. Prinsip-prinsip Desain Pembelajaran. Jakarta: Kencana.

[10] Sugiyono. 2011. Metode Penelitian Kuantitatif Kualitatif dan R\&D Bandung: Alfabeta. 